\title{
FERTILIZER FROM EPPAWELA APATITE : CONVERSION USING ALKALI HYDROXIDE AND QUARTZ
}

\author{
R. P. GUNAWARDANE \\ Department of Chemistry, University of Peradeniya,'Peradeniya,Sri Lanka
}

AND

\author{
H. ANNERSTEN \\ Department of Mineralogy \& Petrology, University of Uppsala, Sweden.
}

(Date of receipt : 07 November 1986)

(Date of acceptance : 08 Aprii 1987)

\begin{abstract}
The reaction of Eppawela apatite with alkali hydroxide and quartz has been investigated in an attempt to convert this mineral into a more soluble phosphate fertilizer. For. complete breakdown four moles of sodium hydroxide are required for each mole of apatite. A molar ratio of apatite : sodium hydroxide : quartz, $1: 4: 2$ at $950^{\circ} \mathrm{C}$ after four hours heating yielded a product possessing a maximum percentage of available phosphorus. Quartz may be replaced by potashfeldspar to obtain a potash containing phosphorus fertilizer but this requires an extended heating time. Replacement of sodium hydroxide by potassium hydroxide in the process gave a product containing high citric acid soluble phosphorus and potassium. The potassium and phosphorus containing phase in the product was identified as potassium calcium phosphate, $\mathrm{KCaPO}_{4}$, which is apparently isostructural with rhenanite, $\mathrm{NaCaPO}_{4}$ Extraction of phosphates from apatite using hot aqueous alkaline solutions followed by crystallisation of the extracts yielded crystalline soluble phosphates suitable for useras a fertilizer.
\end{abstract}

\section{Introduction}

A large deposit of rock phosphate, ${ }^{8}$ apatite occurs in the North Central Province of Sri Lanka at Eppawela. It has been shown that the composition of this apatite from the "leached zone" at Eppawela is close to chlorfluorapatite $^{2,6}$ of formula $\mathrm{Ca}_{5}\left(\mathrm{PO}_{4}\right)_{3}(\mathrm{Cl}, \mathrm{F})$. Available phosphorus content of this mineral is low and as such it is not suitable for direct application as a phosphate fertilizer especially for short terms crops like paddy. Therefore, it is desirable that this mineral be processed to obtain more soluble phosphate fertilizers.

For this conversion it is necessary as far as possible to use locally available and cheap raw materials. Furthermore, capital investment should be low in order to make the process commercially viable.

With this in view, the acidulation ${ }^{7}$ of Eppawela apatite with Paranthan hydrochloric acid and the reaction ${ }^{3,4,5}$ of apatite with soda ash and quartz 
have been investigated. The product developed in the latter case was similar to rhenania phosphate ${ }^{11}$ and it was made by sintering apatite with soda ash and quartz in the molar ratio of $1: 2: 1$ at $900^{\circ} \mathrm{C}$ for 2 hours. The product contains about $26-28 \%$ available $\mathrm{P}_{2} \mathrm{O}_{5}$.

This method may be employed to produce phosphate fertilizer when the rock is not sưitable for acidulation or for phosphoric acid production by the Wet Process. The method can also be used in developing countries where mineral acids such as sulphuric and phosphoric acids are not readily available.

In the present study, the solid state reaction of Eppawela apatite with alkali hydroxide $(\mathrm{NaOH}$ or $\mathrm{KOH})$ and quartz has been investigated in an attempt to replace soda ash by locally produced sodium hydroxide in the process. Furthermore, investigations have also been made on the extraction of phosphate content in apatite using aqueous alkaline solutions.

\section{Experimental}

\subsection{Heating experiments}

The compositions were prepared by mixing the apatite samples (100 mesh) with dried sodium hydroxide/potassium hydroxide or $60 \%$ aqueous solution of sodium hydroxide and quartz/potash feldspar (120 mesh) and heating the mixtures in a muffle furnace using platinum crucibles. After heat treatment the samples were allowed to cool in air for subsequent examination.

\subsection{Solubility studies}

In general, phosphate content available for plant nutrition is determined by estimating either water soluble or citric acid soluble $\mathrm{P}_{2} \mathrm{O}_{5}$. Two per cent citric acid method ${ }^{10}$ has been employed in the present study. Approximately $1.0 \mathrm{~g}$ samples (100 mesh) were extracted with $100 \mathrm{ml}$ of $2 \%$ citric acid using a mechanical shaker operating at about 260 oscillations per minute for $1 / 2 \mathrm{hr}$. The total phosphorus contents of the products were determined by extracting with a mix ture of conc. $\mathrm{HNO}_{3}$ and conc. $\mathrm{HCl}$ followed by $65 \% \mathrm{HClO}_{4}$. The extracts were analysed for phosphorus by the vanadomolybdate method $^{9}$ using a Unicam SP 600 colorimeter at a wavelength of $460 \mathrm{~nm}$.

\subsection{Alkali extraction}

5 g samples of Eppawela apatite (100 mesh B.S.) were treated with $50 \mathrm{ml}$ of aqueous alkaline solutions of different concentrations and stirred for 24 
hours using a magnetic stirrer. The extractions were carried out using $1 \mathrm{M}-5 \mathrm{M}$ solutions of (i) sodium hydroxide, (ii) potassium hydroxide and (iii) sodium carbonate at ambient to $85^{\circ} \mathrm{C}$. The higher temperatures were maintained during the extraction with the aid of a thermostat. The solutions were then filtered and the $\mathrm{pH}$ of the extracts was adjusted in the range $5-6$ with dilute $\mathrm{HNO}_{3}$ for the determination of phosphorus content by the vanadomolybdate method. ${ }^{9}$

\subsection{Identification and analysis}

Sintered products, crystallisation products of some alkali extracts and the residues obtained after extraction were examined by powder X-ray diffraction using $\mathrm{Cu} \mathrm{K}_{\alpha}$ radiation. Potassium contents of some citric acid extracts were estimated using a Perkin-Elmer 305 Atomic Absorption Spectrophotometer with an emission mode at a wavelength of $766 \mathrm{~nm}$.

One $\mathrm{g}$ portions of the products were extracted with $50 \mathrm{ml}$ of de-ionized water for 30 minutes using a mechanical shaker operating at about 260 oscillations per minute for $\mathrm{pH}$ measurement using a CORNING model 5 pH meter.

\section{Results and Discussion}

\subsection{Reaction with sodium hydroxide and quartz}

The results of heating experiments with solid sodium hydroxide and quartz along with the $\mathrm{pH}$ of water extracts of the products are given in Table 4 .

\subsubsection{Reaction conditions and products}

In the compositions containing only apatite and sodium hydroxide in the molar ratios $1: 1,2: 3,1: 2,1: 3$ and $1: 4$, after heat treatment at $950^{\circ} \mathrm{C}$ for 4 hours, the available $\mathrm{P}_{2} \mathrm{O}_{5}$ percentage increases with increase in the alkali/apatite ratio. For instance only about $21 \%$ conversion was observed in 1 : 1 composition while almost $99 \%$ conversion was observed in the $1: 4$ composition. This variation is due to the increase in extent of the reaction. between apatite and alkali. Analysis of these products by powder X-ray diffraction showed the presence of large amounts of free lime in addition to $\alpha$ or $\beta$-rhenanite, $\mathrm{CaNaPO}_{4}$ and some unreacted apatite. Presence of lime was further confirmed by the $\mathrm{pH}$ values (Table 1) of the water extracts of these products.

In the apatite : sodium hydroxide mixtures mentioned above, the $\mathrm{pH}$ values increase with increase in the proportion of sodium hydroxide. This is 


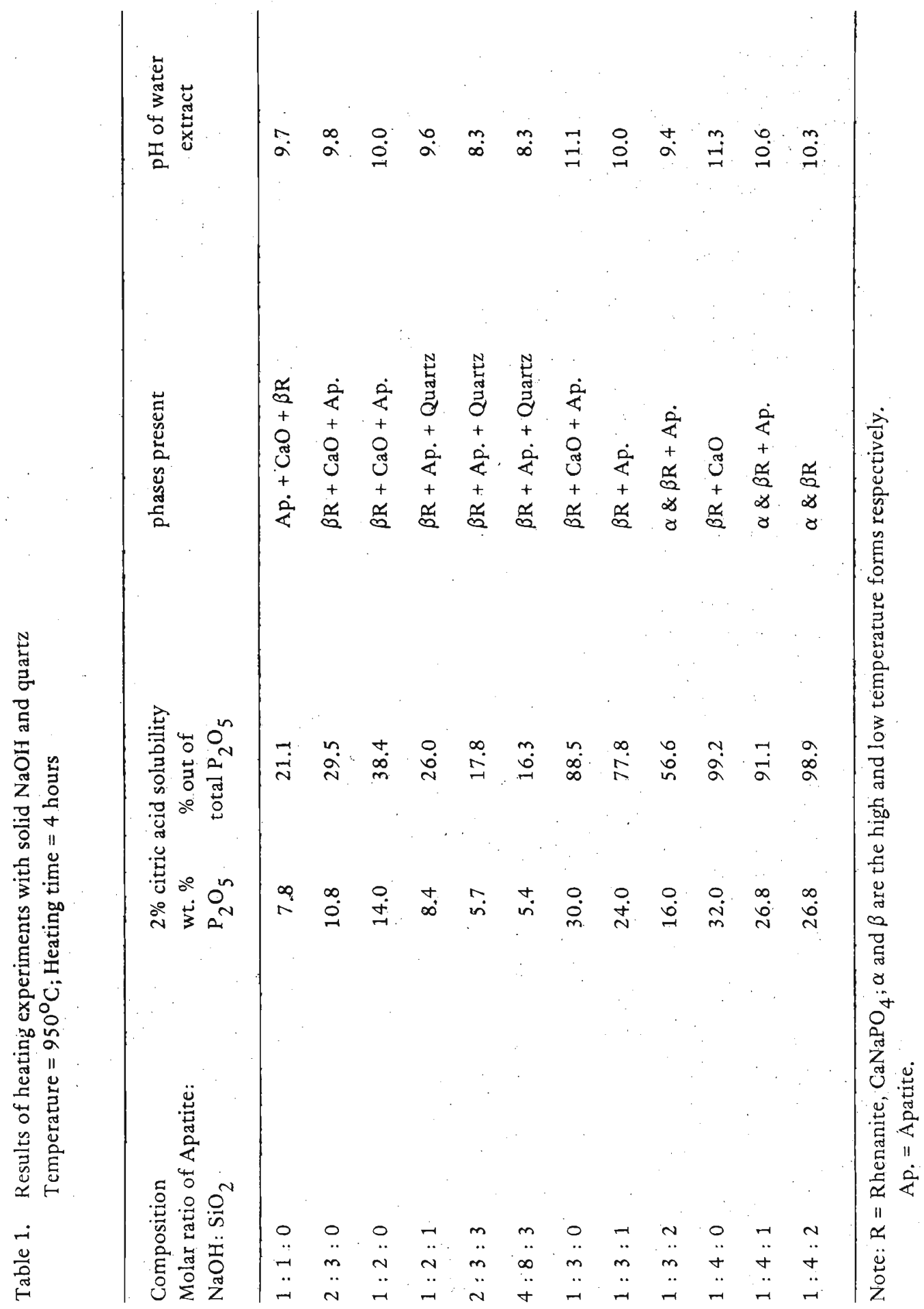


due to the increase in the extent of the reaction between alkali and apatite with the formation of $\mathrm{CaNaPO}_{4}$ and the liberation of increasing amounts of free lime.

Therefore, it is apparent that the mixtures of apatite and sodium hydroxide, in the absence of silica, react to produce free lime. Free lime is considered as an undesirable constituent in a fertilizer. Presence of free lime would create additional problems in storage and transport of fertilizer. Therefore, silica should be added to combine with free lime released in the reaction.

The low values of the percentage conversion observed in the compositions $1: 2: 1,2: 3: 3$ and $4: 8: 3$ (Table 1 ) could be explained to be due to the incomplete reaction and the dilution of the mixtures with silica. Of the mixtures studied, higher percentage conversion values $(>90 \%)$ were obtained with molar ratios of apatite, sodium hydroxide and quartz, $1: 4: 1$ and $1: 4: 2$. The $1: 4: 2$ composition records the highest value $(\sim 99 \%)$. The $\mathrm{pH}$ values of the water extracts of these two compositions are relatively low indicating the absence of free lime. Furthermore, X-ray powder pattern of the $1: 4: 2$ composition confirmed that this composition does not contain any trace of free lime.

In all these products the major constituent was identified as rhenanite ( $\alpha$ or $\beta \mathrm{CaNaPO}_{4}$ ). Dicalcium silicate, $\mathrm{Ca}_{2} \mathrm{SiO}_{4}$, formed by the reaction of quartz with lime goes into solid solution with rhenanite as shown in previous studies. ${ }^{6}$ As such, only rhenanite solid solution has been detected in the products by powder X-ray diffraction.

\subsubsection{Rate of conversion}

The reaction of Eppawela apatite with sodium hydroxide resembles its reaction with soda ash. ${ }^{6}$ Furthermore, the phases present in the products are in complete agreement with previous phase equilibrium studies. ${ }^{6}$ Complete conversion to rhenanite has been achieved using soda ash at $900^{\circ} \mathrm{C}$ after 2 hours heating. On the other hand, kinetic studies on the reaction of apatite with solid sodium hydroxide and quartz revealed that the most suitable temperature is $950^{\circ} \mathrm{C}$. For complete conversion heating duration should be increased to 4 hours unlike in the case of soda ash process.

In order compare the rates of the two reactions, the compositions apatite : soda ash : quartz $1: 2: 1$ and apatite : sodium hydroxide : quartz $1: 4: 2$ were heated in a muffle furnace from ambient to $1000^{\circ} \mathrm{C}$ at a heating rate $5^{\circ} \mathrm{C}$ per minute. Over the temperature range $500^{\circ}$ to $1000^{\circ} \mathrm{C}$ small samples were removed at $50^{\circ}$ intervals and cooled rapidly in air and the available $\mathrm{P}_{2} \mathrm{O}_{5}$ contents determined. Under these conditions the effect of temperature on percentage conversion of the two compositions is compared in Figure 1. 


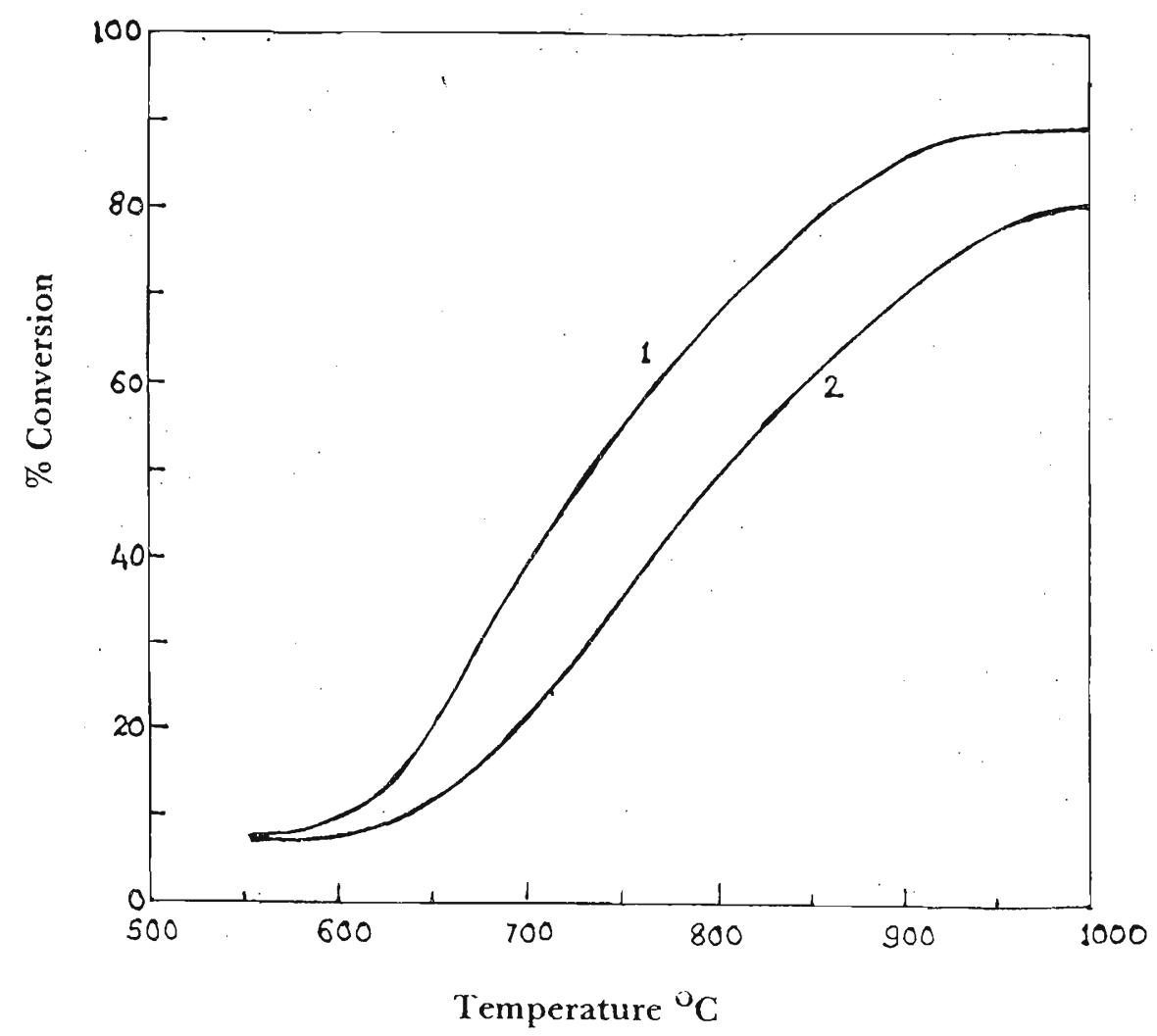

Figure 1. Relationship between temperature and percentage conversion (\% wi $\mathrm{P}_{2} \mathrm{O}_{5}$ out of total $\mathrm{P}_{2} \mathrm{O}_{5}$ ) of the compositions,

(1) apatite : $\mathrm{Na}_{2} \mathrm{CO}_{3}:$ quartz, $1: 2: 1$

(2) apatite : $\mathrm{NAOH}:$ quartz, $1: 4: 2$, at a heating rate of $5^{\circ} \mathrm{C}$ per minute. 
In both cases the percentage conversion increases with rise in temperature from $600^{\circ} \mathrm{C}$ reaching the highest value $(87 \%)$ in the composition containing soda ash around $900^{\circ} \mathrm{C}$. In the composition apatite : sodium hydroxide : quartz, $1: 4: 2$ maximum conversion $(81 \%)$ was observed at about $950^{\circ} \mathrm{C}$. Heat treatment of the latter sample at $950^{\circ} \mathrm{C}$ for further two hours resulted in almost $100 \%$ conversion. This confirms that the most suitable temperature for the conversion using sodium hydroxide and quartz is $950^{\circ} \mathrm{C}$ and a further reduction of reaction temperature cannot be achieved without appreciably affecting the available $\mathrm{P}_{2} \mathrm{O}_{5}$ content. This study also confirms that soda ash is more effective than sodium hydroxide in the conversion.

\subsubsection{Use of aqueous $\mathrm{NaOH}$}

Since aqueous sodium hydroxide is manufactured locally it is of interest to investigate the possible use of aqueous solution of sodium hydroxide in the process. Experiments carried out using $60 \%$ aqueous solution of sodium hydroxide and the molar ratio of apatite $: \mathrm{NaOH}:$ quartz, $1: 4: 2$, revealed that an additional drying stage is in fact necessary prior to firing at $950^{\circ} \mathrm{C}$. Initial mixing was found to be easy. with the aqueous solution and drying sould be done at $120-150^{\circ} \mathrm{C}$ for 1 hour. The final product obtained after firing at $950^{\circ} \mathrm{C}$ contained rhenanite as the major phase with about $26 \%$ available $\mathrm{P}_{2} \mathrm{O}_{5}$. Thus it is possible to replace solid sodium hydroxide by an aqueous solution in the process.

\subsection{Reaction with sodium hydroxide and potashfeldspar}

It is theoretically possible to replace quartz by potashfeldspar to produce a fertilizer containing potassium in addition to phosphorus. This is advantageous because both phosphorus and potassium are important plant nutrients.

Assuming the ideal formula of potashfeldspar as $\mathrm{KAlSi}_{3} \mathrm{O}_{8}$, the molar ratio of apatite, sodium hydroxide and feldspar, $3: 11: 1$ respectively, has been calculated to be equivalent to the optimum ratio observed for compositions containing apatite, sodium hydroxide and quartz. Therefore, molar ratios close to this calculated value $(3: 11: 1)$ has been investigated and the results are shown in Table 2.

About $80 \%$ conversion has been observed in all the compositions (Table 2) after firing at $950^{\circ} \mathrm{C}$ for 4 hours. When heating time was increased to 8 hours the percentage conversion was raised to $\sim 85 \%$. Almost $100 \%$ conversion was effected by raising the temperature to $1100^{\circ} \mathrm{C}$ for 8 hours. Therefore, to obtain $100 \%$ conversion of available phosphorus with feldspar, increase of reaction temperature or heating time or both may be necessary. 


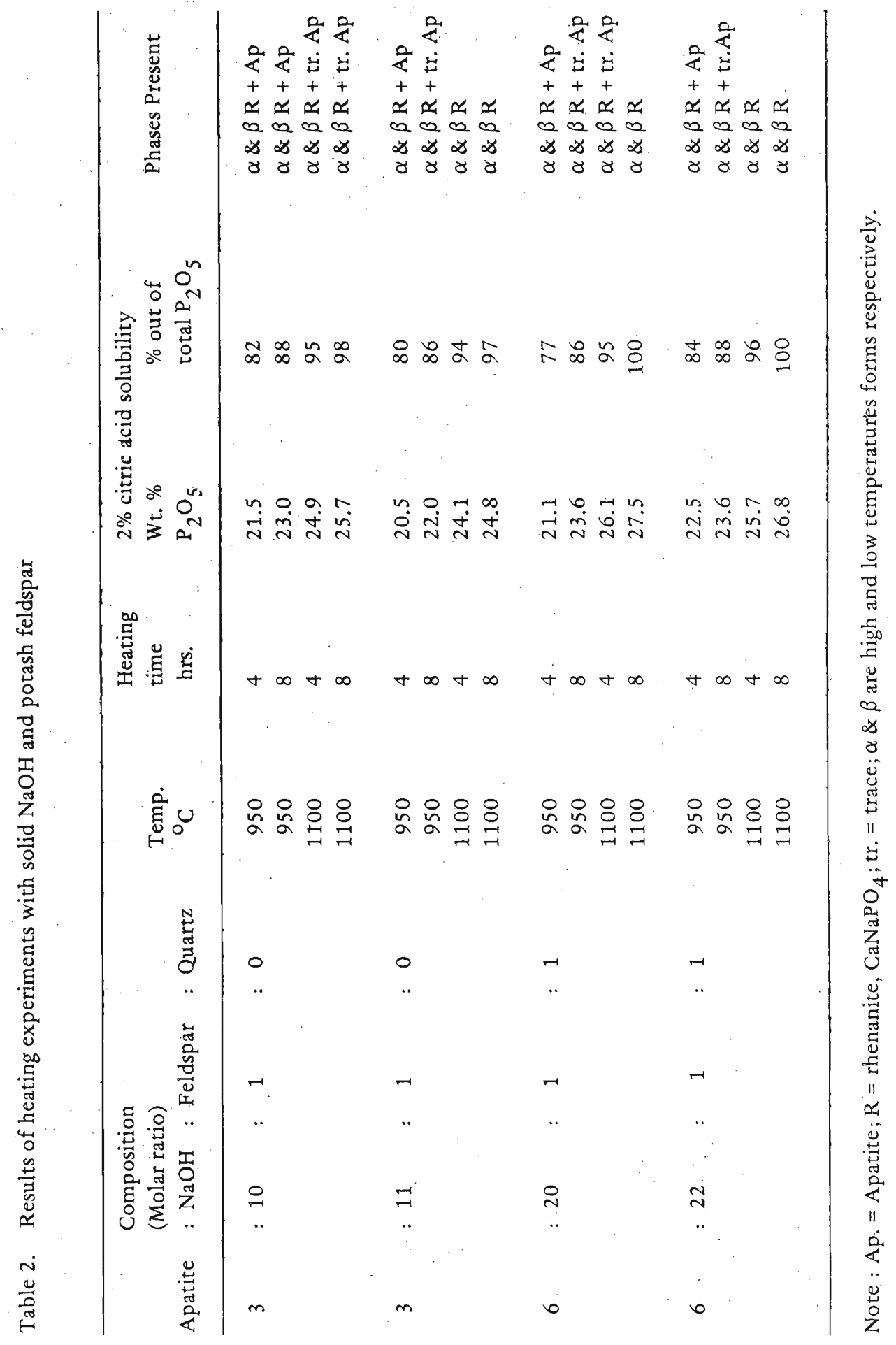


No specific potassium containing phase has been identified in the products. The major phase in the product was identified as $\alpha$ or $\beta$ rhenanite by powder X-ray diffraction. It is likely that potassium goes into solid solution with rhenanite. This was evident from potassium analysis of the citric acid extracts of the products [Table 3 (i)] .

Table 3. Potash contents of citric acid extracts of some products $\left(950^{\circ} \mathrm{C} / 4 \mathrm{~h}\right)$.

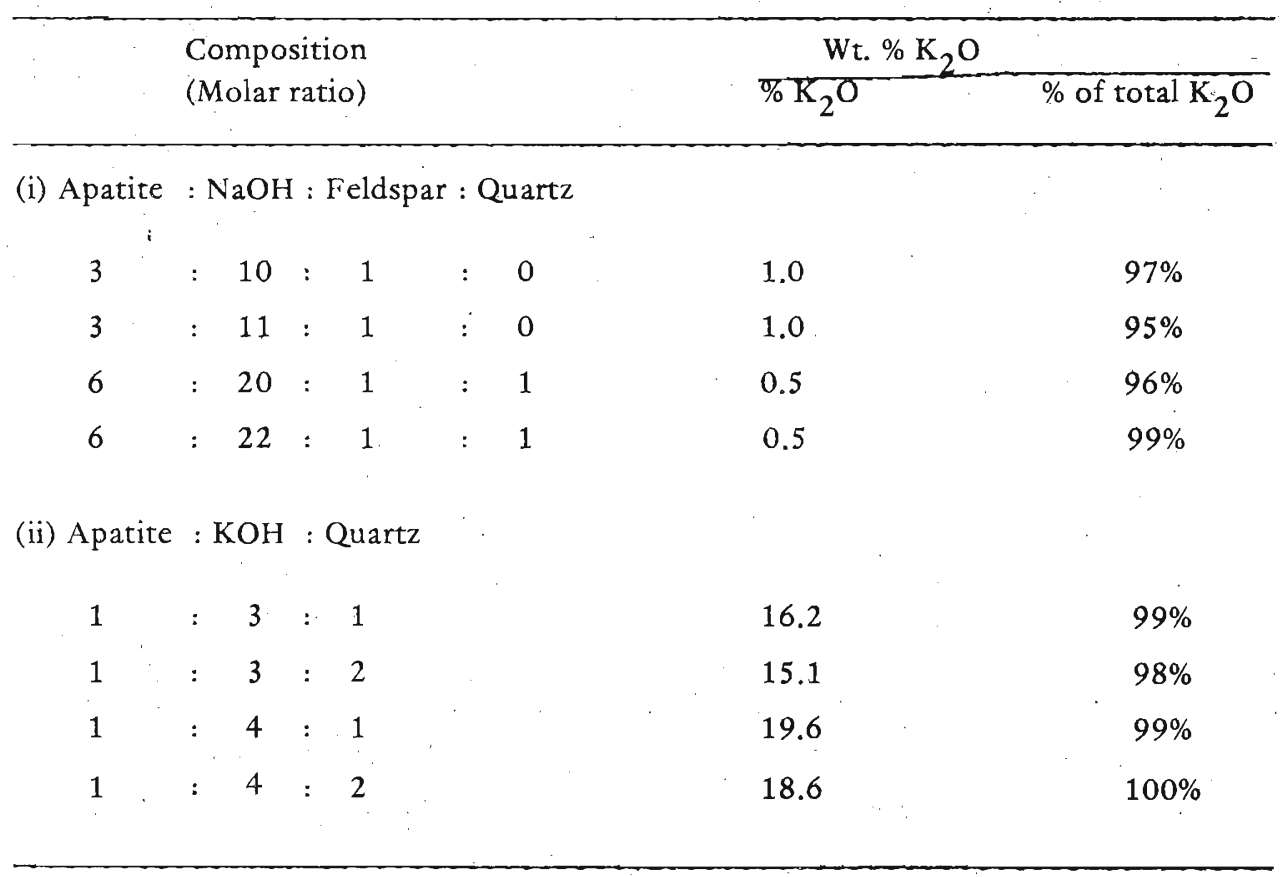

The feldspar sample used in the present study, when chemically analysed was found to contain $9.2 \%$ wt $\mathrm{K}_{2} \mathrm{O}$ (approximately half the theoretical value of $16.9 \%$ wt $\mathrm{K}_{2} \mathrm{O}$ ) and $2.9 \%$ wt $\mathrm{Na}_{2} \mathrm{O}$. Hence this sample contained $30 \%$ less alkali than theoretical : the deficiency presumably being made up by calcium.

The potassium contents of the citric acid extracts of the products [Table 3(i)] show low values $\left(0.5-1.0 \%\right.$ wt $\left.\mathrm{K}_{2} \mathrm{O}\right)$ owing to the unexpected low content of potassium in the feldspar sample. However, about $95-99 \%$ of the total potassium in the product is extractable in $2 \%$ citric acid. 
Insoulble residues after citric acid extraction, typically $1-2$ wt $\%$, were collected, dried and examined. X-ray powder diffraction studies indicated that the residues contain carnegieite, $(\mathrm{Na}, \mathrm{K}) \mathrm{AISiO}_{4}$, residual apatite and calcium monoferrite, $\mathrm{CaFe}_{2} \mathrm{O}_{4}$.

\subsection{Reaction with solid potassium hydroxide and quartz}

The results of heating experiments of apatite with solid $\mathrm{KOH}$ and quartz are presented in Table 4.

Table 4. Results of heating experiments with solid $\mathrm{KOH}$ and quartz Temperature $=950^{\circ} \mathrm{C}$; Heating time $=4$ hours

\begin{tabular}{|c|c|c|c|}
\hline \multirow{2}{*}{$\begin{array}{l}\text { Composition } \\
\text { Molar ratio of } \\
\text { Apatite: } \mathrm{KOH}: \mathrm{SiO}_{2}\end{array}$} & \multicolumn{2}{|c|}{$2 \%$ citric acid solubility } & \multirow[t]{2}{*}{ Phases present } \\
\hline & $\begin{array}{l}\text { wt. \% } \\
\mathrm{P}_{2} \mathrm{O}_{5}\end{array}$ & $\begin{array}{l}\% \text { out of } \\
\text { total } \mathrm{P}_{2} \mathrm{O}_{5}\end{array}$ & \\
\hline $1: 1: 0$ & 5.9 & 16.8 & Ap. $+\mathrm{CaO}+\mathrm{CaKPO}_{4}$ \\
\hline $2: 3: 0$ & 8.0 & 24.5 & $\mathrm{CaKPO}_{4}+\mathrm{Ap} .+\mathrm{CaO}$ \\
\hline $1: 2: 0$ & 10.3 & 33.9 & $\mathrm{CaKPO}_{4}+\mathrm{Ap} .+\mathrm{CaO}$ \\
\hline $1: 2: 1$ & 6.0 & 21.4 & $\mathrm{CaKPO}_{4}+\mathrm{Ap}$ \\
\hline $2: 3: 3$ & 5.9 & 20.6 & $\begin{array}{c}\text { Ap. }+{ }_{\text {CaKPO }}{ }^{+}+ \\
\text {tr. Quartz }\end{array}$ \\
\hline $4: 8: 3$ & 5.2 & 18.2 & $\begin{array}{l}\mathrm{CaKPO}_{4}+\mathrm{Ap} .+ \\
\text { tr. Quartz }\end{array}$ \\
\hline $1: 3: 0$ & 21.9 & 81.6 & $\mathrm{CaKPO}_{4}+\mathrm{CaO}+\mathrm{Ap}$ \\
\hline $1: 3: 1$ & 18.4 & 74.1 & $\mathrm{CaKPO}_{4}+\mathrm{Ap} .+$ tr. $\mathrm{CaO}$ \\
\hline $1: 3: 2$ & 14.0 & 60.1 & $\mathrm{CaKPO}_{4}+\mathrm{Ap}$ \\
\hline $1: 4: 0$ & 22.6 & 94.1 & $\mathrm{CaKPO}_{4}+\mathrm{CaO}$ \\
\hline $1: 4: 1$ & 20.7 & 92.2 & $\begin{array}{l}\mathrm{CaKPO}_{4}+\text { tr. Ap. }+ \\
\quad \text { tr. } \mathrm{CaO}\end{array}$ \\
\hline $1: 4: 2$ & 20.4 & 96.6 & $\mathrm{CaKPO}_{4}$ \\
\hline
\end{tabular}

\subsubsection{Reaction conditions}

The same trends observed in the compositions containing apatite, $\mathrm{NaOH}$ and quartz have been observed in the compositions containing apatite, $\mathrm{KOH}$ and quatz as well. The extent of the reaction increases with increase in potassium hydroxide content from the molar ratio of apatite : $\mathrm{KOH}, 1: 1$ up to $1: 4$. As in the case of sodium hydroxide reaction, it is evident that one mole of apatite requires four moles of potassium hydroxide for complete reaction. Apatite and potassium hydroxide react together to give a large amount of free lime and a phase containing both phosphorus and potassium. 
Among the compositions studied $1: 4: 0,1: 4: 1$ and $1: 4: 2$ gave high yields $\left(>92 \%\right.$ wt $\left.\mathrm{P}_{2} \mathrm{O}_{5}\right)$ of available phosphorus. Since $1: 4: 0$ contains excess lime it is not suitable as a fertilizer. A composition of $1: 4: 2$ (Table 4) fulfills the requirements of a $\mathrm{P}, \mathrm{K}$-fertilizer possessing $\sim 20 \%$ wt available $\mathrm{P}_{2} \mathrm{O}_{5}$ and $\sim 18 \%$ wt $\mathrm{K}_{2} \mathrm{O}$. The $2 \%$ citric acid soluble potash contents of sintered apatite, $\mathrm{KOH}$ and quartz compositions are shown in Table 3 (ii). These results show that almost $100 \%$ of the potassium in the product is soluble in $2 \%$ citric acid and thus available for plant nutrition.

Therefore, the use of potassium hydroxide instead of sodium hydroxide has an added advantage of producing a fertilizer possessing high phosphorus as well as high potassium contents.

\subsubsection{Nature of products}

The powder X-ray diffraction pattern of $\mathrm{K}, \mathrm{P}$-containing phase in the product was found to be very similar to $\beta$ rhenite. Synthetic and X-ray powder diffraction investigations revealed that this phase is in fact $\mathrm{CaKPO}_{4},{ }^{1}$, which is isostructural with rhenanite. Similar to $\alpha$ and $\beta$ rhenanite $\mathrm{CaKPO}_{4}$ is almost $100 \%$ soluble in $2 \%$ citric acid, making its total phosphorus and potassium contents available for plant nutrition.

DTA was performed on $\mathrm{CaKPO}_{4}$ using Stranton-Redcroft Model DTA 673 up to $1000^{\circ} \mathrm{C}$ at a heating rate of $10^{\circ} \mathrm{C}$ per minute. A reversible transition has been observed in the temperature range $660-680^{\circ} \mathrm{C}$. The hysteresis effect of this transition is not very prominent indicating that the structural change is not very drastic. It has also been observed using TG that there is no weight loss or gain associated with the transition. This shows that $\mathrm{CaKPO}_{4}$ exists in two crystalline forms which possibly have slightly different crystal structures. It was, however not possible to differentiate the two forms by using powder X-ray diffraction.

\subsection{Alkali extraction of phosphates}

Results of extraction studies with aqueous sodium hydroxide and potassium hydroxide solutions are given in Table 5 . With both these solutions it has been observed that the extractable $\mathrm{P}_{2} \mathrm{O}_{5}$ increases with increase in concentration from $1 \mathrm{M}$ to $5 \mathrm{M}$. The extractable phosphorus content increases with increase in temperature from ambient up to $60^{\circ} \mathrm{C}$ and then decreases with rise in temperature in all the concentrations studied using aqueous sodium hydroxide. However, in the case of potassium hydroxide gradual increase in extractable $\mathrm{P}_{2} \mathrm{O}_{5}$, was observed with increase in temperature up to $75^{\circ} \mathrm{C}$.

It appears therefore that the optimum temperature for extraction with $\mathrm{NaOH}$ is around $60^{\circ} \mathrm{C}$. Five $\mathrm{M} \mathrm{NaOH}$ solution at $60^{\circ} \mathrm{C}$ gave the maximum 


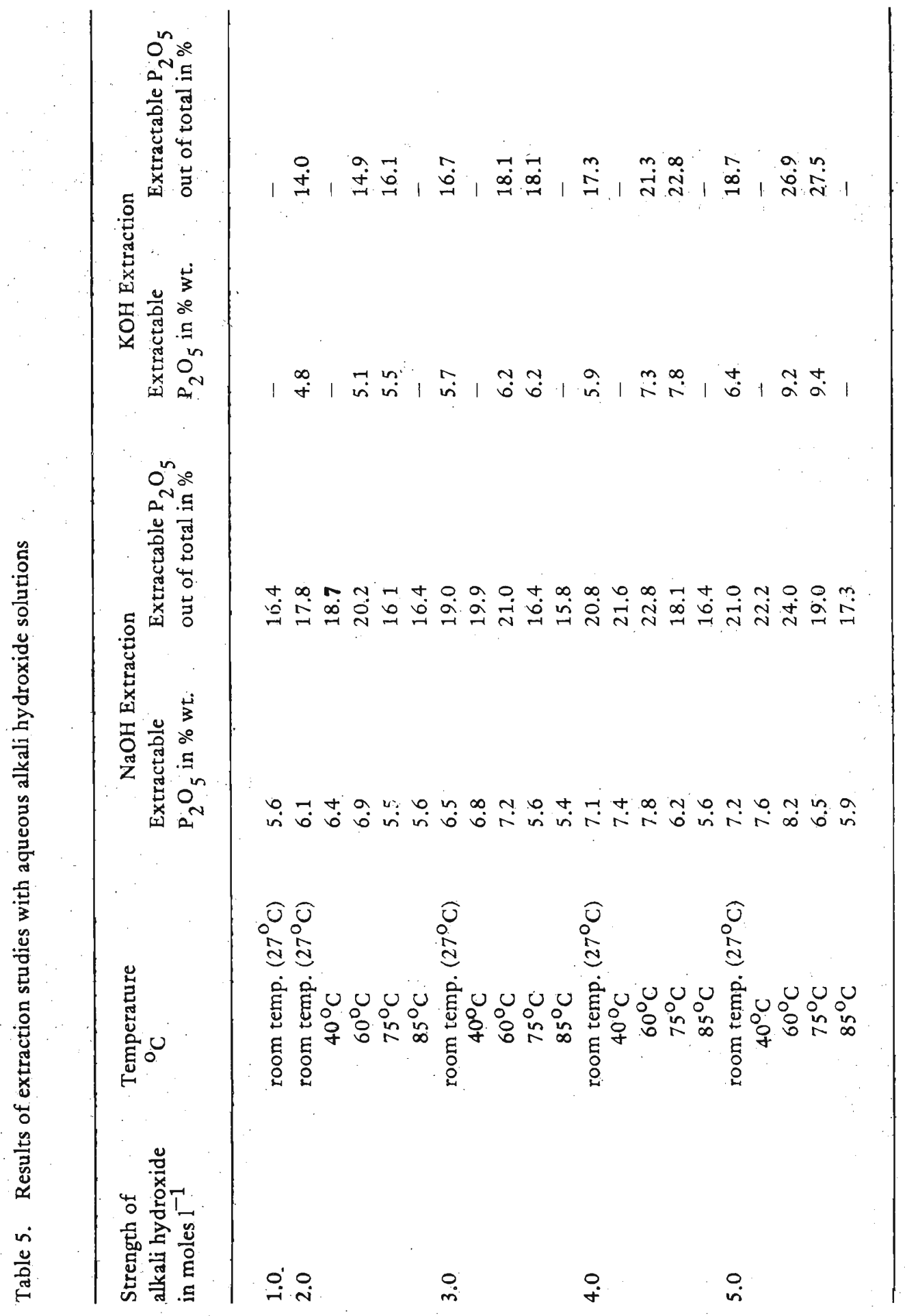


value $(8.2 \%)$ of extractable $\mathrm{P}_{2} \mathrm{O}_{5}$ which is equivalent to $24 \%$ of the total $\mathrm{P}_{2} \mathrm{O}_{5}$ in the rock sample. A slightly higher maximum value of $9.4 \%$ extractable $\mathrm{P}_{2} \mathrm{O}_{5}$ was observed using $5 \mathrm{M} \mathrm{KOH}$ solution at $75^{\circ} \mathrm{C}$. This value amounts to $27.5 \%$ of the total $\mathrm{P}_{2} \mathrm{O}_{5}$ in the sample, which is only slightly higher than the value observed for aqueous $\mathrm{NaOH}$.

Results of the extraction studies using aqueous sodium carbonate solutions are presented in the Table 6 . With aqueous sodium carbonate it has been observed that the extractable $\mathrm{P}_{2} \mathrm{O}_{5}$ content increases with increase in concentration from $1 \mathrm{M}$ to $5 \mathrm{M}$ and at concentrations higher than $5 \mathrm{M}$ no appreciable increase has been observed. As in the case of $\mathrm{NaOH}$, extractable $\mathrm{P}_{2} \mathrm{O}_{5}$ content increases with rise in temperature from ambient to $60^{\circ} \mathrm{C}$ and then decreases with increase in temperature. Therefore, available data indicate that $5 \mathrm{M}$ aqueous sodium carbonate solution and a temperature of about $60^{\circ} \mathrm{C}$ are suitable for extraction. Under these conditions a maximum extractable $\mathrm{P}_{2} \mathrm{O}_{5}$ value of $17.3 \%$ was obtained, which is equivalent to $50 \%$ of the total $\mathrm{P}_{2} \mathrm{O}_{5}$ in the original sample. The total $\mathrm{P}_{2} \mathrm{O}_{5}$ content of the Eppawela apatite sample used in the present study was experimentally estimated to be $34.2 \%$ wt.

The solubility of Eppawela apatite in water is very small, only about $0.5-1.0 \%$ wt $\mathrm{P}_{2} \mathrm{O}_{5}$ being soluble. However, $2 \%$ citric acid soluble $\mathrm{P}_{2} \mathrm{O}_{5}$ is about $6 \%$. In this context the maximum extractable $\mathrm{P}_{2} \mathrm{O}_{5}$ contents observed using aqueous $\mathrm{NaOH}$ and $\mathrm{KOH}\left(\sim 8-9 \%\right.$ wt $\left.\mathrm{P}_{2} \mathrm{O}_{5}\right)$ are not very significant. On the other hand, aqueous sodium carbonate can be considered as a fairly efficient extracting agent.

Crystallization of the alkaline extracts has been attempted by concentrating the extracts by evaporation followed by cooling. Crystallisation of sodium carbonate extracts after concentration yielded large needle shaped crystals of high birefringence. X-ray powder diffraction studies on the crystalline products indicate that they are not pure sodium phosphates. It is most likely that the crystalline products contain mixed crystals of carbonate-phosphates of sodium. These crystalline products are water soluble and as such it may be possible to use this material as a phosphate fertilizer in certain acidic soils.

\section{Conclusions}

For complete conversion of apatite to citric acid soluble product four moles of sodium hydroxide (or 2 moles of $\mathrm{Na}_{2} \mathrm{O}$ ) are required for each mole of apatite. The optimum molar ratio of apatite: $\mathrm{NaOH}:$ quartz was found to be $1: 4: 2$. Unlike in the case of soda ash process, use of sodium hydroxide necessitates higher temperature $\left(950^{\circ} \mathrm{C}\right)$ and increased heating time 


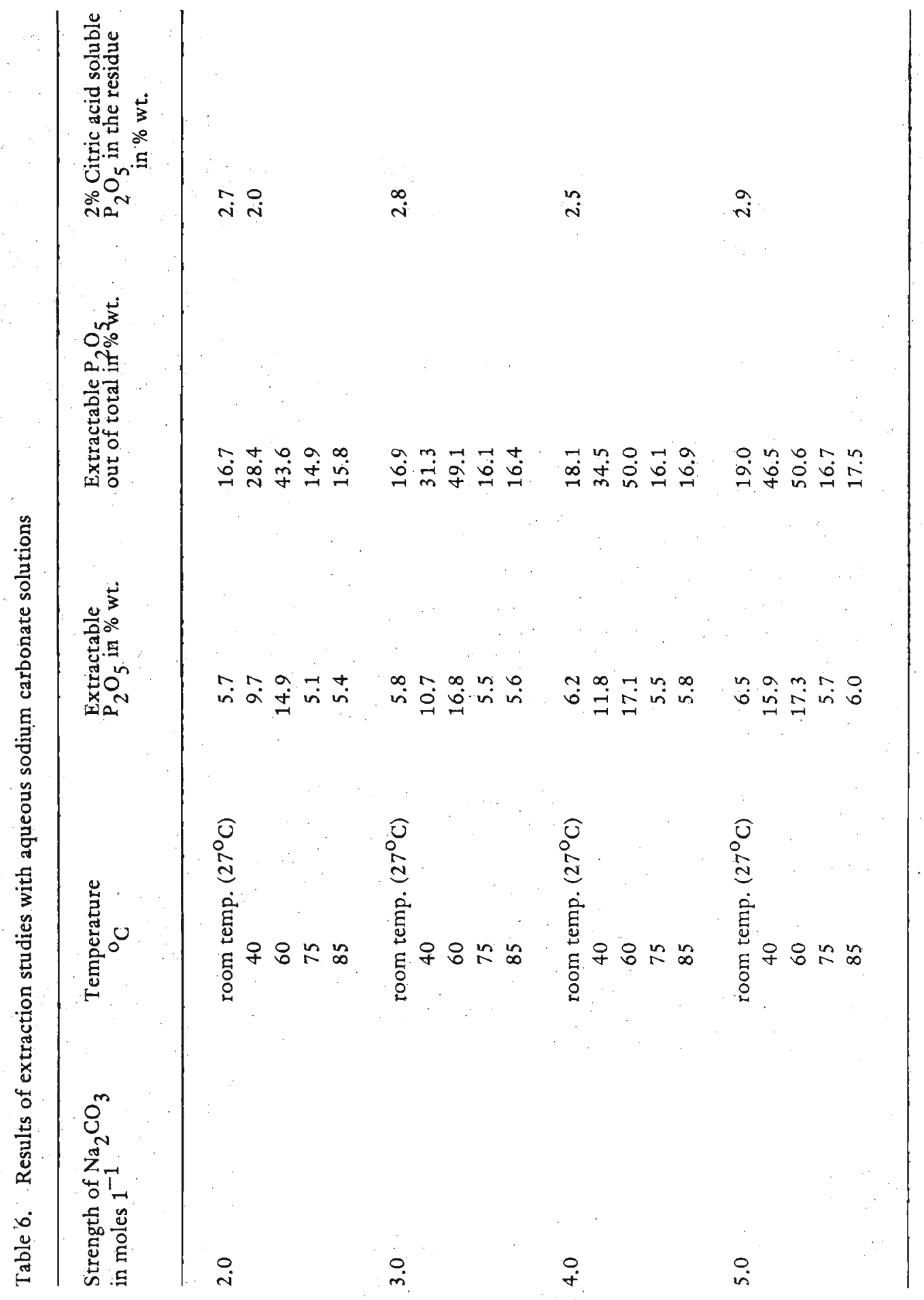


(4 hours). It is possible to replace solid $\mathrm{NaOH}$ by $60 \%$ aqueous solution of $\mathrm{NaOH}$ in the process but in this case an additional drying stage is necessary before sintering.

Quartz may be replaced by potashfeldspar in the composition to obtain a potassium containing phosphate fertilizer. However, the reaction appears to be sluggish and as such either a higher temperature $\left(1100^{\circ} \mathrm{C}\right)$ or increased heating time ( $8 \mathrm{hrs}$.) may be necessary to obtain a fertilizer with a high yield of available phosphorus.

The replacement of $\mathrm{NaOH}$ by $\mathrm{KOH}$ results in the formation of a fertilizer containing both phosphorus and potassium. The major phase in the product was identified as $\mathrm{CaKPO}_{4} \cdot \mathrm{CaKPO}_{4}$ is completely soluble in $2 \%$ citric acid, thus its total phosphorus and potassium contents are available for plant nutrition.

It is evident that an aqueous solution of sodium carbonate is more effective in extracting phosphate from Eppawela apatite than the alkali hydroxide solutions. About $50 \%$ of the total $\mathrm{P}_{2} \mathrm{O}_{5}$ in the rock can be extracted with $5 \mathrm{M}$ aqueous sodium carbonate solution at $60^{\circ} \mathrm{C}$. These extracts may be crystallised to obtain crystalline water soluble phosphates.

\section{Acknowledgements}

We are grateful to the International Seminar in Chemistry of the Uppsala University, Sweden for financial assistance.

\section{References}

1. BREDIG, M.A. (1942) J. Phys. Chem. $46: 747$.

2. CORBRIDGE, D.E.C. (1974) The Structural Chemistry of Phosphorus. Elsevier Publishing Company, Amsterdam, London, New York.

3. GUNAWARDANE; R.P. (1979) Proc. Sri Lanka Assoc. Adv. Sci. $35: 56$.

4. GUNAWARDANE, R.P. (1982) J. Natn. Sci. Coun. Sri Lanka 10(2) : 181-194.

5. GUNAWARDANE, R.P. \& GLASSER, F.P. (1979) Fertilizer Material from apatite, British Patent No. 7931090, British Patent Office, London, U.K.

6. GUNAWARDANE, R.P. \& GLASSER, F.P. (1979) J. Mater. Sci. 14 : 2797-2810. 
7. JAYASEKARA, K.S.; TENNAKOON, D.T.B. \& GUNAWARDANE, R.P. (1978) Proc. Sri Lanka Assoc. Adv. Sci. 34 : 59.

8. JAYAWARDANA, D.E. DE S. (1976) The Eppawela Carbonatite Complex in North-West Sri Lanka, Economic Bulletin No. 3, Geological Survey Department, Colombo.

9. JEFFERY, P.G. (1971) Chemical methods of rock analysis, Pergamon Press, Oxford.

10. PIERRE, W.H. \& NORMAN, A.G. (1953.) Soil and fertlizer phosphorus in crop nutrition, Academic Press, London, New York.

11. UlLmANN, F. (1955) Encyklopadie der Technischen Chemie, Vol. 6, Urban and Schwarzenberg, Munchen, Berlin, Wien. 